\title{
Rancang Bangun Penerangan Jalan Raya Berbasis Arduino Uno
}

\author{
Sari Ramadhani ${ }^{*}$, Yuda Alferinanda ${ }^{1}$ dan Asnil ${ }^{1}$ \\ ${ }^{1}$ Jurusan Teknik Elektro, Fakultas Teknik, Universitas Negeri Padang \\ *e-mail: sariramadhani711@gmail.com
}

(Diterima: 2 Juni 2020, direvisi: 8 Juli 2020, disetujui: 26 Juli 2020)

\begin{abstract}
Abstrak
Pemborosan dalam penggunaan energi listrik kini tampaknya telah menjadi kebiasaan. Seperti dalam pemakaian lampu jalan yang tetap menyala meski dalam keadaan yang tidak memerlukan penerangan menjadi salah satu kebiasaan tersebut. Dengan kebutuhan akan energi listrik yang terus meningkat, salah satu solusinya yaitu menerapkan sistem otomatis pada penerangan jalan dengan menggunakan sensor Light Dependent Resistor (LDR) dan sensor Passive Infrared Receiver (PIR) yang bertujuan agar pemakaian energi listrik dapat lebih efesien. Dalam jurnal ini penulis ingin membuat rancang bangun penerangan jalan raya berbasis arduino uno. Secara umum prinsip kerja dari alat ini adalah lampu penerangan jalan akan otomatis menyala dengan cahaya redup saat keadaan mulai gelap dengan menggunakan sensor LDR. Lampu juga akan otomatis menyala terang apabila sensor (LDR dan PIR) berhasil mendeteksi sehingga akan menampilkan informasi pada tampilan LCD. Dan jika sensor (LDR dan PIR) tidak mendeteksi apapun lampu jalan akan kembali meredup sehingga dapat menghemat pemakaian energi listrik. Hasil dari rancang bangun ini telah bekerja sesuai dengan yang direncanakan yaitu menghidupkan lampu secara otomatis menggunakan sensor Light Dependent Resistor (LDR) dan sensor Passive Infrared Receiver (PIR). Dan menampilkan informasi pada layar LCD.
\end{abstract}

Kata Kunci: Lampu Penerangan Jalan, Sensor Light Dependent Resistor (LDR), sensor Passive Infrared Receiver (PIR), Arduino Uno.

\begin{abstract}
Waste in the use of electrical energy now seems to have become a habit. For example, the use of street lights that remain on even in conditions that do not require lighting is one of these habits. With the increasing need for electrical energy, one solution is to implement an automatic system for street lighting using a Light Dependent Resistor (LDR) sensor and a Passive Infrared Receiver (PIR) sensor which aims to make the use of electrical energy more efficiently. In this journal the author wants to make a road lighting design based on Arduino Uno. In general, the working principle of this tool is that the street lights will automatically turn on with dim light when things get dark using the LDR sensor. The lamp will also light up automatically when the sensors (LDR and PIR) successfully detect so that it will display information on the LCD display. And if the sensors (LDR and PIR) do not detect anything in the street lights will dim again so that it can save electricity consumption. The results of this design have worked as planned, namely turning on the lights automatically using the Light Dependent Resistor (LDR) sensor and the Passive Infrared Receiver (PIR) sensor and displays information on the LCD screen.
\end{abstract}

Keywords: Street Lighting, Light Dependent Resistor (LDR) Sensor, Passive Infrared Receiver (PIR) sensor, Arduino Uno. 


\section{PENDAHULUAN}

Dalam kehidupan sehari-hari manusia tidak bisa lepas dari kebutuhan akan cahaya. namun selama ini sumber-sumber cahaya yang ada belum dimanfaatkan secara maksimal untuk mempermudah pemenuhan kebutuhan manusia. Disamping itu untuk dapat mengenali sebuah objek visual, manusia membutuhkan sebuah penerangan yang memengaruhi penglihatan manusia. Oleh karena itu diperlukan lampu sebagai sumber penerangan untuk dapat menunjang aktifitas visual manusia saat berada diluar ruangan. Tanpa adanya pencahayaan yang baik mengakibatkan aktivitas diluar ruangan apalagi saat berkendara akan terganggu dikarenakan minimnya cahaya[1].

Disamping itu dalam kehidupan sehari-hari, manusia cenderung menyukai hal-hal yang bersifat otomatis. Intensitas cahaya yang berasal dari lampu apabila diarahkan ke sebuah sensor dapat di manfaatkan dalam sistem otomatis penyalaan lampu. Untuk itu dalam mengatasi masalah-masalah tersebut diperlukan alat yang bisa mengontrol sistem otomatis penyalaan lampu.

Dalam hal ini penulis merancang alat otomatis yang dapat membantu atau meringankan pekerjaan manusia. Penulis merancang suatu alat yaitu penerangan jalan raya berbasis arduino uno, yang mana saat malam hari lampu akan hidup otomatis jika dilewati oleh objek, objek yang dimaksud adalah kendaraan dan manusia. Cahaya dari lampu jalan diatur dari intensitas cahaya yang dideteksi oleh sensor cahaya yaitu sensor LDR sehingga penghematan pemakaian energi listrik dapat dilakukan dikarenakan intensitas lampu akan disesuaiakan dengan kondisi lalu lintas jalan, sedangkan sensor PIR pada perancangan ini berfungsi untuk mendeteksi kehadiran objek[2].

\section{Lampu Penerangan Jalan}

Lampu penerangan jalan adalah lampu yang digunakan sebagai penerangan jalan pada malam hari sehingga mengguna jalan dapat melihat dengan jelas jalan yang akan dilalui dimalam hari, sehingga dapat meningkatkan keselamatan lalu lintas dan keamanan untuk pengguna jalan[3].

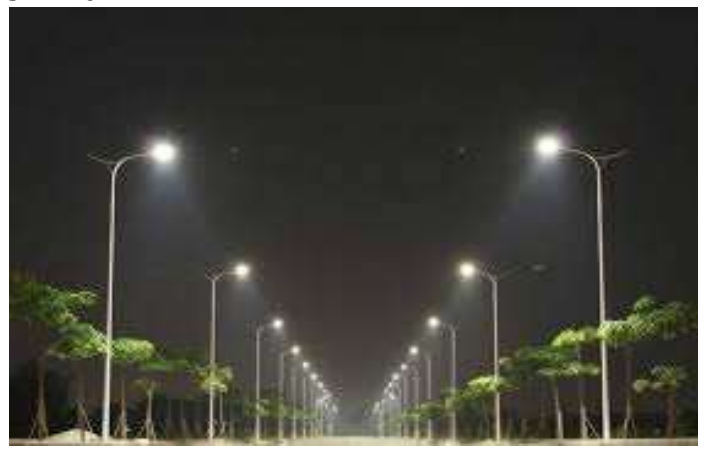

Gambar 1. Lampu Penerangan Jalan

\section{Arduino Uno}

Arduino uno adalah sebuah board yang menggunakan mikrokontroller ATmega328. Arduino uno memiliki 14 input/output digital (6 output untuk PWM), 6 analog input, resonator kristal keramik $16 \mathrm{MHz}$, Koneksi USB, soket adaptor, pin header ICSP, dan tombol reset. Hal inilah yang dibutuhkan untuk mensupport mikrokontrol secara mudah terhubung dengan kabel power USB atau kabel power supply adaptor AC ke DC atau juga battery[4]. 


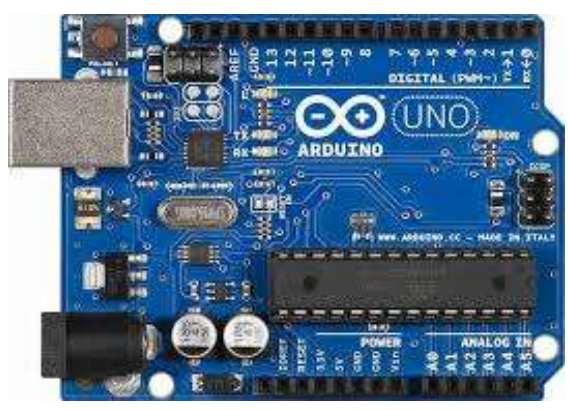

Gambar 2. Arduino Uno

\section{Sensor LDR (Light Dependent Resistor)}

LDR adalah sebuah sensor cahaya yang bersifat fotokonduktif, yaitu sensor yang akan memberikan perubahan tahanan (resistansi) pada sel-selnya, semakin tinggi intensitas cahaya yang diterima maka semakin kecil pula nilai tahanannya[5]. Cara kerja dari sensor LDR ini adalah dapat memutuskan dan menyambungkan aliran listrik berdasarkan cahaya. semakin banyak cahaya yang mengenai sensor maka nilai resistansinya akan menurun, dan sebaliknya jika semakin sedikit cahaya yang mengenai sensor maka niai resistansinya semakin membesar[6].

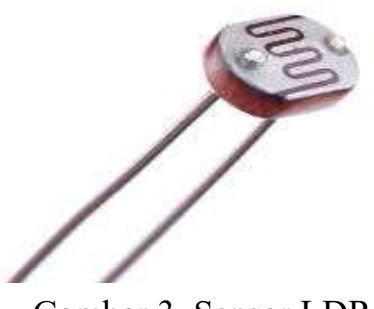

\section{Gambar 3. Sensor LDR}

\section{Sensor PIR (Passive Infrared Receiver)}

Sensor PIR ini bekerja dengan menangkan energi panas yang dihasilkan dari pancaran sinar inframerah pasif yang dimiliki setiap benda dengan suhu benda diatas nol mutlak. Pancaran sinar inframerah inilah yang kemudian ditangkap oleh Pyroelectric sensor yang merupakan inti dari sensor PIR ini sehingga menyebabkan Pyroelectic sensor yang terdiri dari galium nitrida, caesium nitrat dan litium tantalate menghasilkan arus listrik[7].

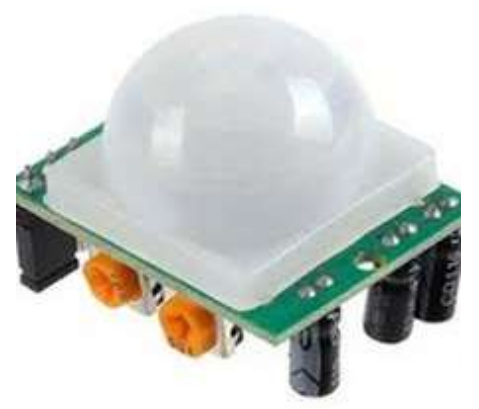

Gambar 4. Sensor PIR 


\section{Baterai Lithium Ion}

Baterai lithium ion adalah salah satu dari beberapa jenis baterai yang ada. Baterai jenis ini dapat diisi ulang dan merupakan baterai yang ramah lingkungan karena tidak mengandung bahan - bahan berbahaya seperti baterai Ni-Cd dan Ni-MH[8].

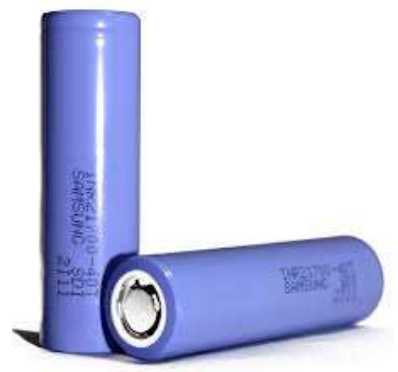

Gambar 5. Baterai Lithium Ion

\section{LCD (Liquid Crystal Display) dengan Modul I2C}

LCD adalah perangkat yang berfungsi sebagai media penampil dengan memanfaatkan kristal cair sebagai objek penampil utama. modul I2C akan lebih memperhemat penggunaan pin arduino yang akan digunakan, contohnya saja 17 dengan menggunakan modul I2C maka hanya diperlukan 4 buah pin arduino, yaitu pin SCL, pin SDA, pin VCC dan pin GND[9].

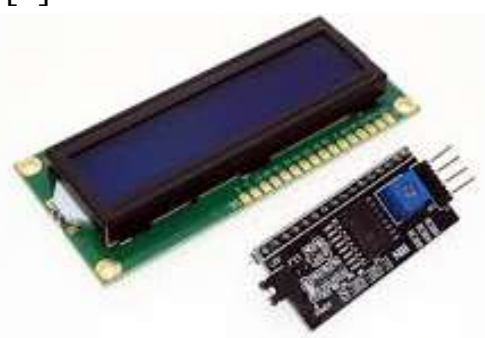

Gambar 6. LCD

\section{LED (Light Emitting Diode)}

LED adalah komponen elektronika yang dapat memancarkan cahaya monokromatik ketika diberikan tegangan maju. Cara kerja LED hanya akan memancarkan cahaya apabila dialiri tegangan maju (bias forward) dari Anoda menuju ke Katoda[10].

\section{METODE}

Metode penelitian ini berupa rancang bangun, yaitu terdiri dari blok diagram, gambar rangkaian, dan desain alat. Gambar 7 menunjukkan metode penelitian rancang bangun yang digunakan.

Penjelasan dari blok diagram rancang bangun penerangan lampu jalan berbasis arduino uno :

- Baterai jenis 18650 merupakan supply atau sumber listrik yang akan digunakan.

- IC Regulator 7805 berfungsi untuk menurunkan sumber tegangan dari baterai yang mana tegangan awal baterai adalah 7.4 Volt menjadi 5 Volt.

- Arduino Uno merupakan pusat pengontrolan kerja alat, arduino menerima data sensor dan mengolah data tersebut sesuai dengan keluaran yang diinginkan. 
- LCD (liquid crystal display) berfungsi untuk menampilkan data yang dibaca oleh sensor LDR dan sensor PIR.

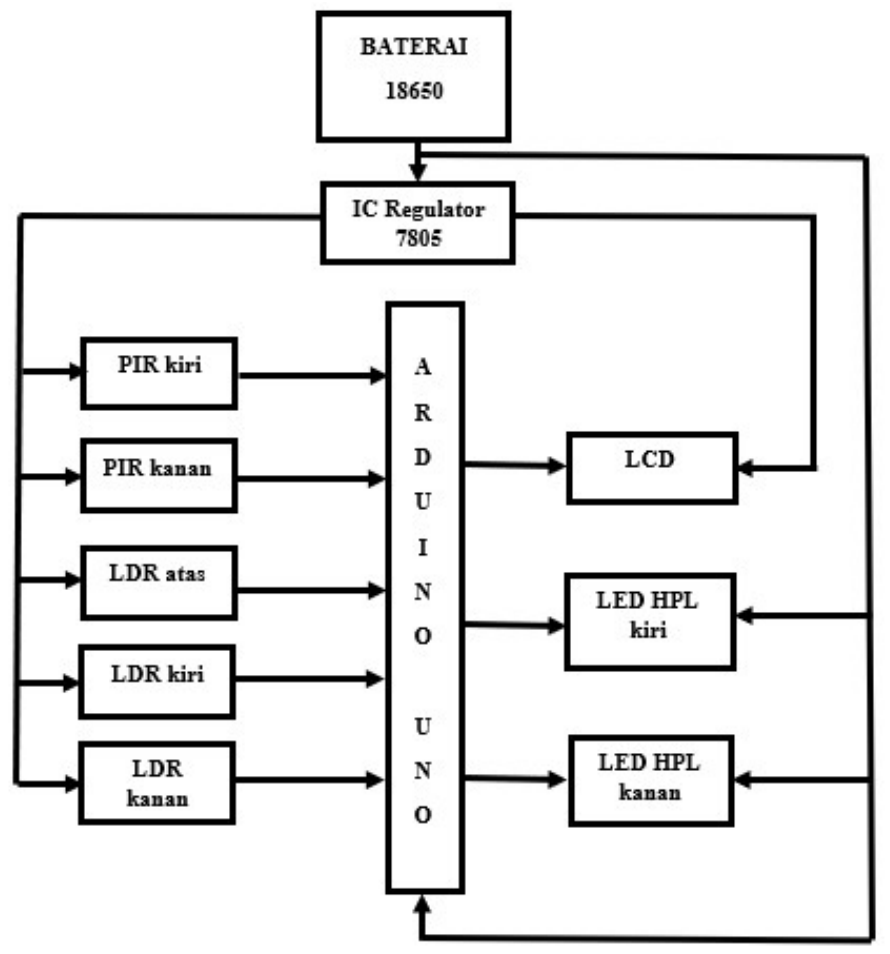

Gambar 7. Blok Diagram

- LDR (light dependent resistor) bagian atas akan aktif apabila keadaan mulai gelap atau keadaan malam sensor ini akan otomatis menghidupkan lampu jalan dengan cahaya redup.

- LDR (light dependent resistor) bagian kiri dan kanan berfungsi mendeteksi cahaya atau sinar dari lampu kendaraan sehingga lampu penerangan jalan yang mulanya redup otomatis akan lebih terang.

- Sensor PIR (passive infra red) bagian kiri dan kanan ini berfungsi untuk menangkap pancaran sinyal inframerah atau gerakkan pada makhluk hidup sehingga jika sensor mendeteksi lampu jalan yang mulanya redup akan otomatis terang.

- Led HPL (high power led) bagian kiri dan kanan merupakan output dari sensor LDR dan sensor PIR.

Pada gambar 8 dapat dijelaskan bahwa baterai jenis 18650 merupakan sumber tegangan untuk seluruh komponen yang ada dalam rangkaian. Dengan bantuan IC Regulator 7805 berfungsi untuk menurunkan tegangan dari baterai yang mana tegangan awal baterai adalah 7.4 Volt menjadi 5 Volt, sedangkan Kapasitor ELCO 100 $\mu$ F/16V yang terpasang pada output tegangan IC Regulator 7805 berfungsi untuk meratakan tegangan 5Volt yang telah diturunkan oleh IC Regulator 7805 tadi sebelum di supply ke 
komponen lainnya. Komponen yang membutuhkan supply tegangan 5 Volt adalah Modul LCD I2C, Sensor LDR, dan sensor PIR, sedangkan Arduino Uno sedangkan LED menggunakan tegangan masukan langsung dari Baterai 18650 dengan tegangan masukkan sebesar 7.4 Volt.

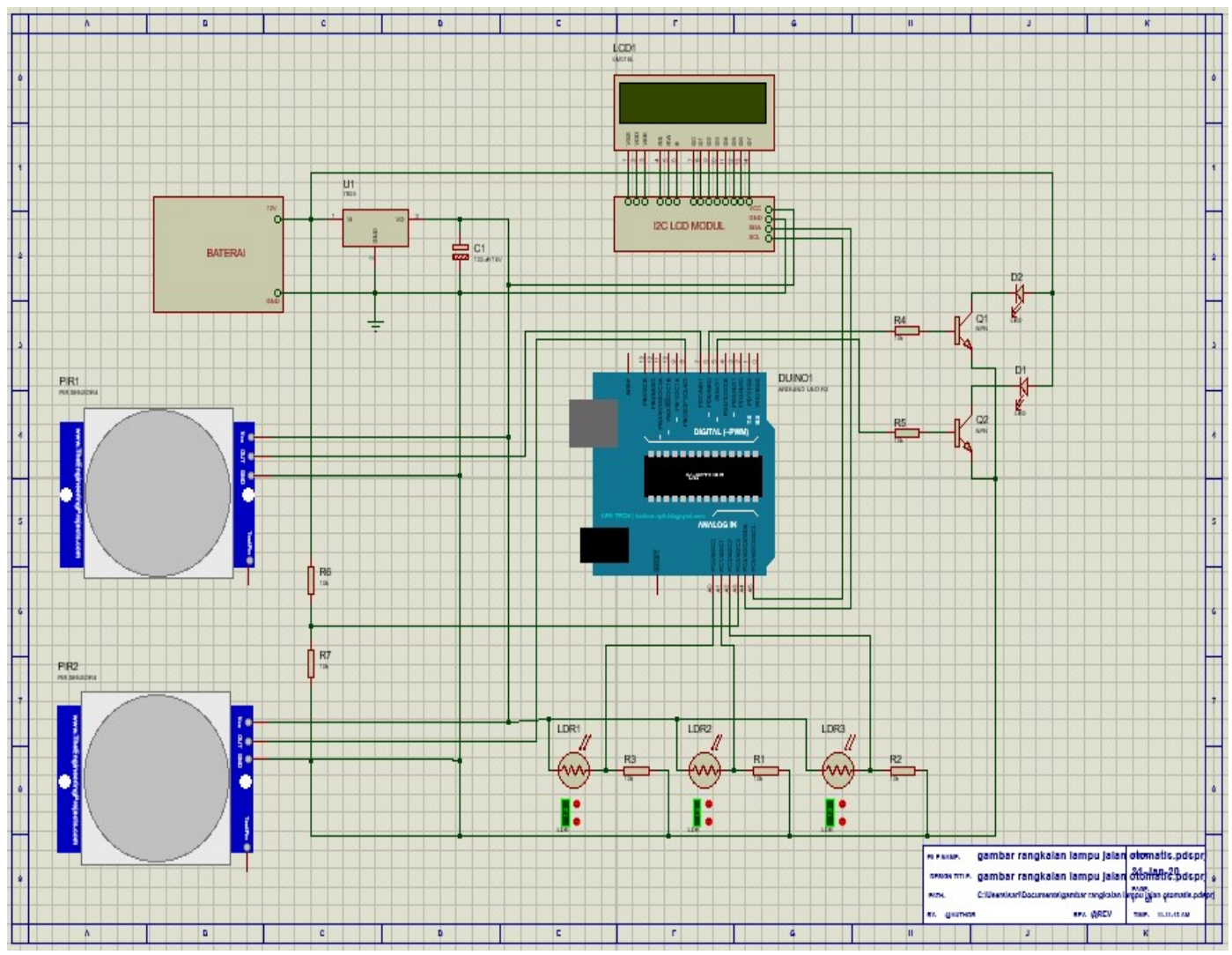

Gambar 8. Gambar Rangkaian

Kemudian untuk mensimulasikan rangkaian pada kondisi jalan sebenarnya, maka dibuatlah sebuah miniatur jalan dan system penerangannya. Desain dan dimensi dapat dilihat pada gambar 9. Kemudian penyusunan alat pada miniature dapat dilihat pada gambar 10 .
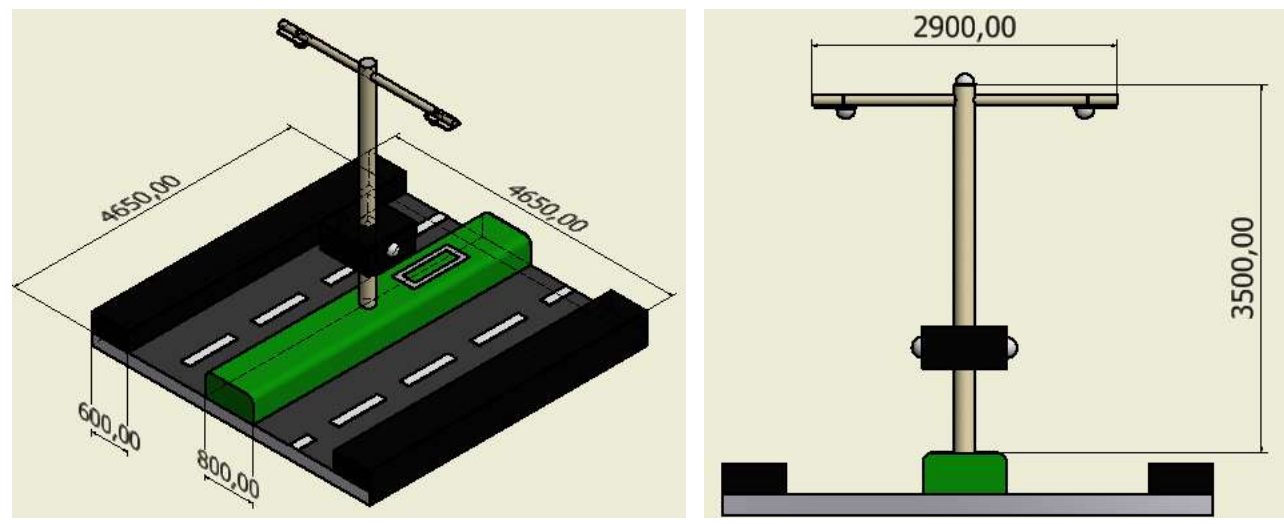

Gambar 9. Desain miniatur 


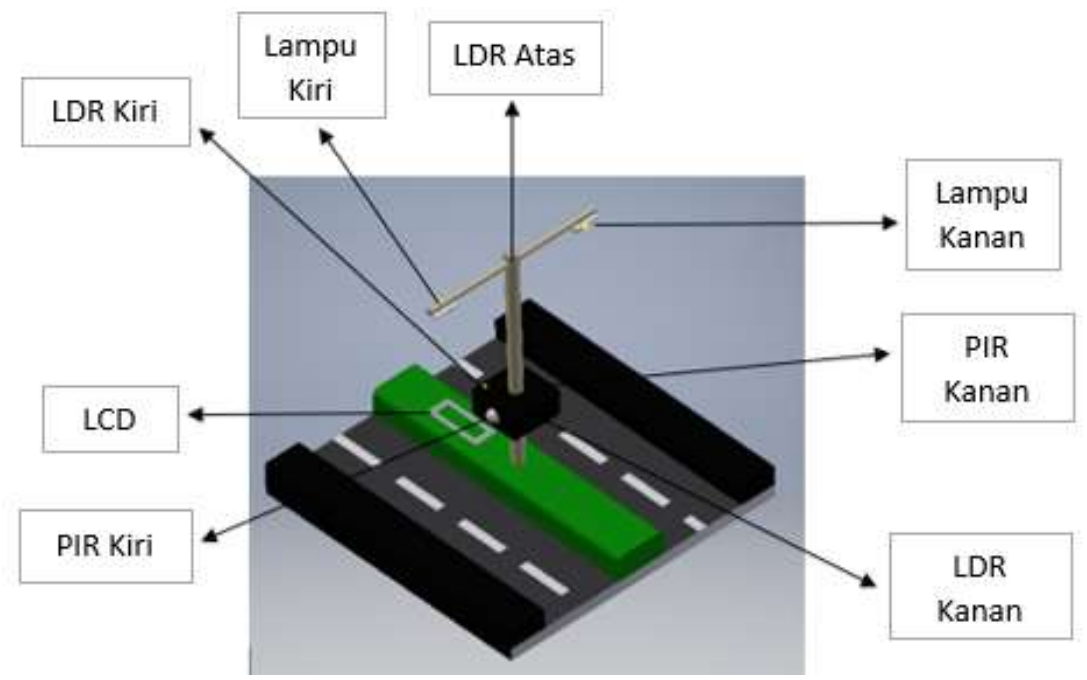

Gambar 10. Keterangan Miniatur

\section{HASIL DAN PEMBAHASAN}

\section{Pengujian Tegangan Sensor LDR}

Dalam pengujian alat ini langkah pertama yang diuji adalah besar tegangan masukkan dan keluaran dari masing masing sensor. Yang pertama pengujian tegangan masukkan dan keluaran dari sensor LDR (light dependent resistor) dapat dilihat pada tabel 1 dan gambar 11

Tabel 1. Pengujian Tegangan Sensor LDR

\begin{tabular}{cc}
\hline Tegangan Masukkan & Tegangan Keluaran \\
\hline 4.99 Volt & 4.53 Volt
\end{tabular}

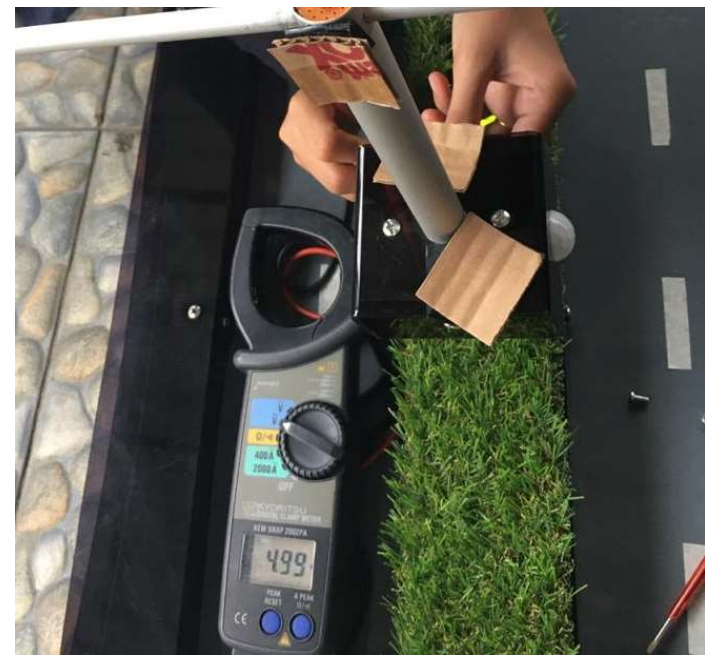

a)

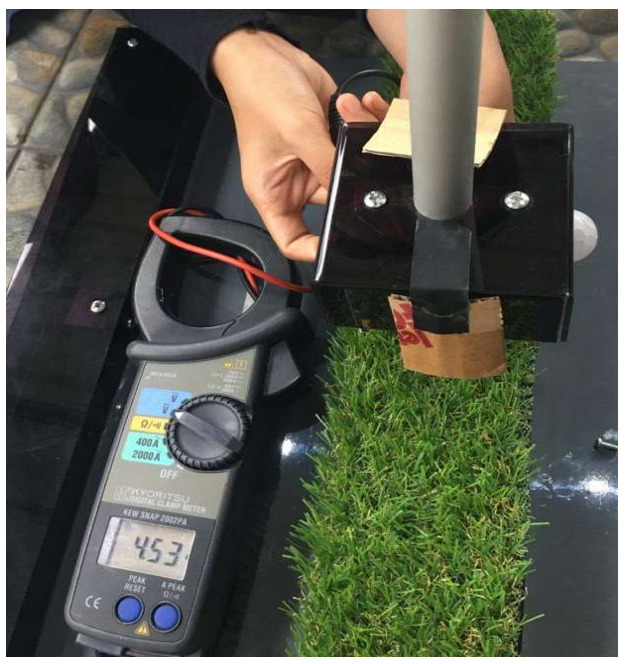

b)

Gambar 11. Tegangan a) masukan b) keluaran Sensor LDR 


\section{Pengujian Tegangan Sensor PIR}

Langkah selanjutnya adalah pengujian tegangan masukkan, tegangan keluaran, dan waktu aktif sensor sensor PIR (passive infrared receiver) data pengujian dapat dilihat dari tabel 2 dan gambar 12 serta gambar 13

Tabel 2 Pengujian Sensor PIR

\begin{tabular}{cccc}
\hline $\begin{array}{c}\text { Sensor } \\
\text { P } \\
\text { I }\end{array}$ & $\begin{array}{c}\text { Tegangan } \\
\text { Masukkan }\end{array}$ & $\begin{array}{l}\text { Tegangan } \\
\text { Keluaran }\end{array}$ & $\begin{array}{c}\text { Waktu } \\
\text { aktif } \\
\text { Lampu }\end{array}$ \\
\cline { 2 - 4 } R & 4.95 Volt & 3.32 Volt & $4.22 \mathrm{~s}$ \\
\hline
\end{tabular}
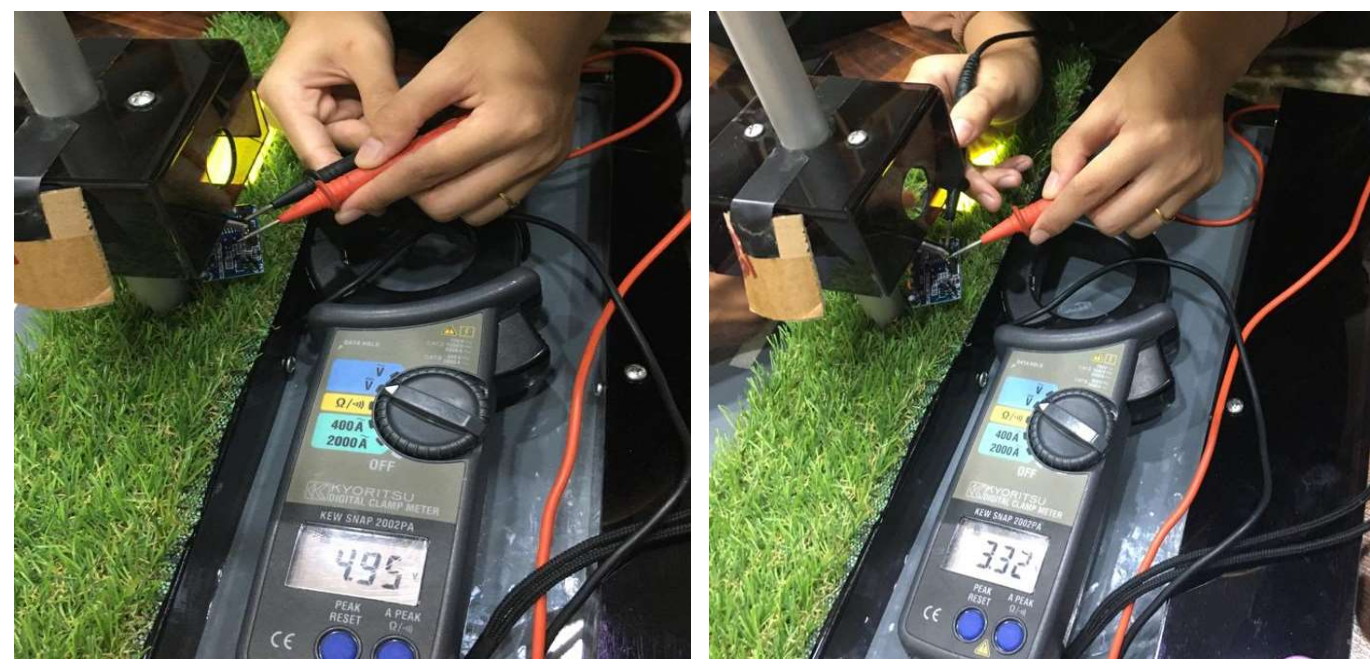

Gambar 12. Tegangan a) masukan b) keluaran Sensor PIR

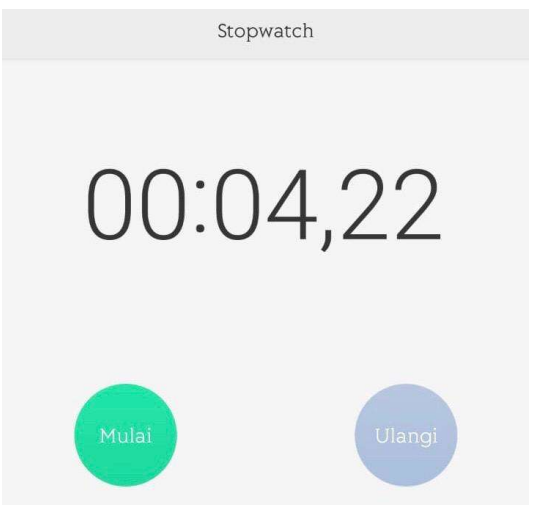

Gambar 13. Waktu Aktif Sensor PIR

\section{Pengujian Sistem Alat}

\section{Sensor LDR Atas}

Gambar 14 Merupakan gambar saat sensor LDR atas aktif yang menandakan bahwa keadaan mulai gelap atau hari sudah malam. Sehingga lampu jalan hidup secara otomatis dengan cahaya yang redup. Dan tampilan awal LCD menunjukkan data yang masih kosong. Karena sensor LDR kiri dan kanan serta sensor PIR kiri dan kanan belum mendeteksi. 

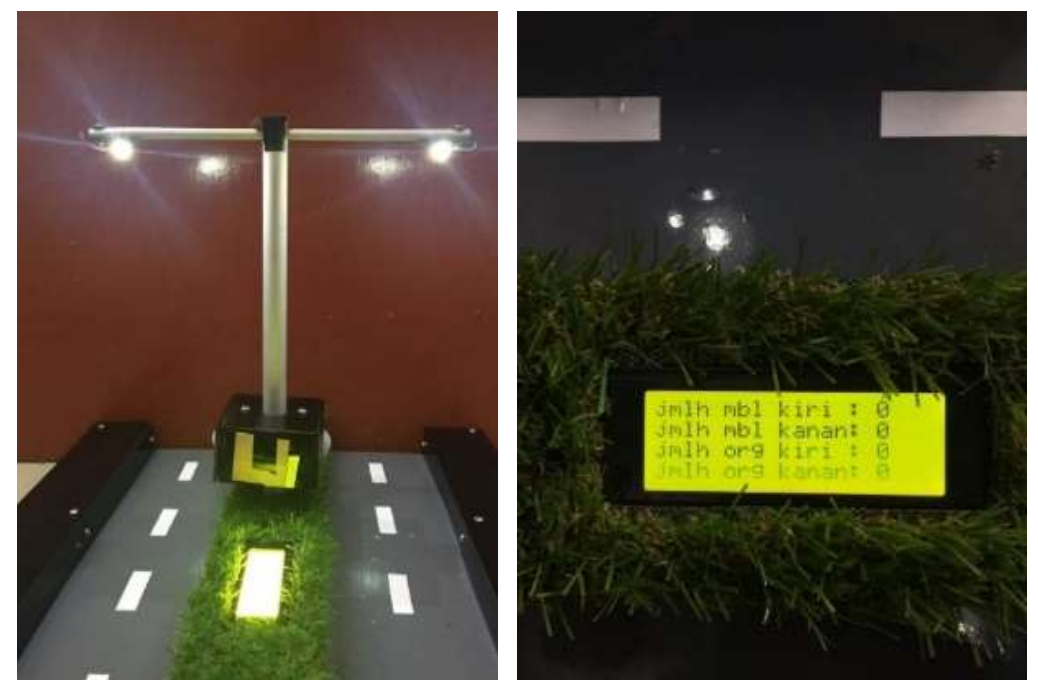

Gambar 14. Sensor LDR Atas Aktif

\section{Sensor LDR Kanan}

Gambar 15 Menunjukkan bahwa sensor LDR kanan mendeteksi adanya sinar atau cahaya dari kendaraan. Sehingga lampu kanan jalan yang awalnya redup menjadi terang. Sehingga terbaca oleh tampilan LCD bahwa ada kendaraan yang melalui jalan.

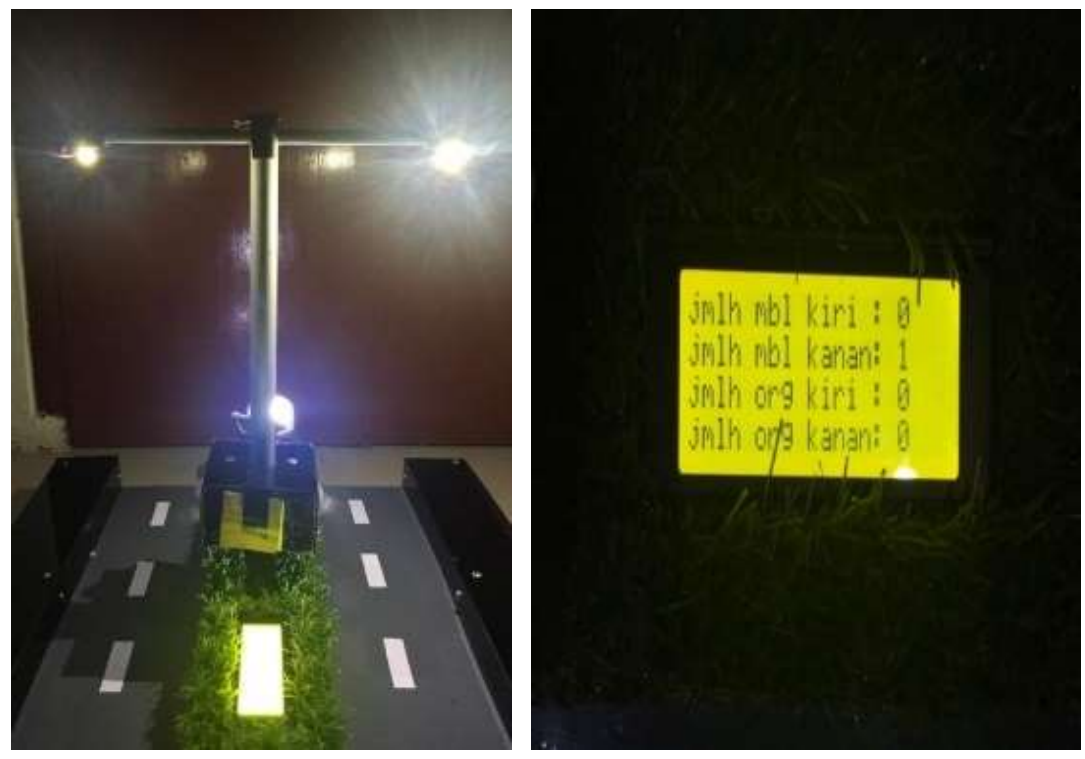

Gambar 15. Sensor LDR Kanan Mendeteksi

Sensor LDR Kiri

Gambar 16 merupakan gambar sensor LDR kiri mendeteksi adanya cahaya kendaraan sehingga lampu jalan bagian kiri terlihat terang dibandingkan lampu jalan bagian kanan, sehingga akan terbaca oleh tampilan LCD. 

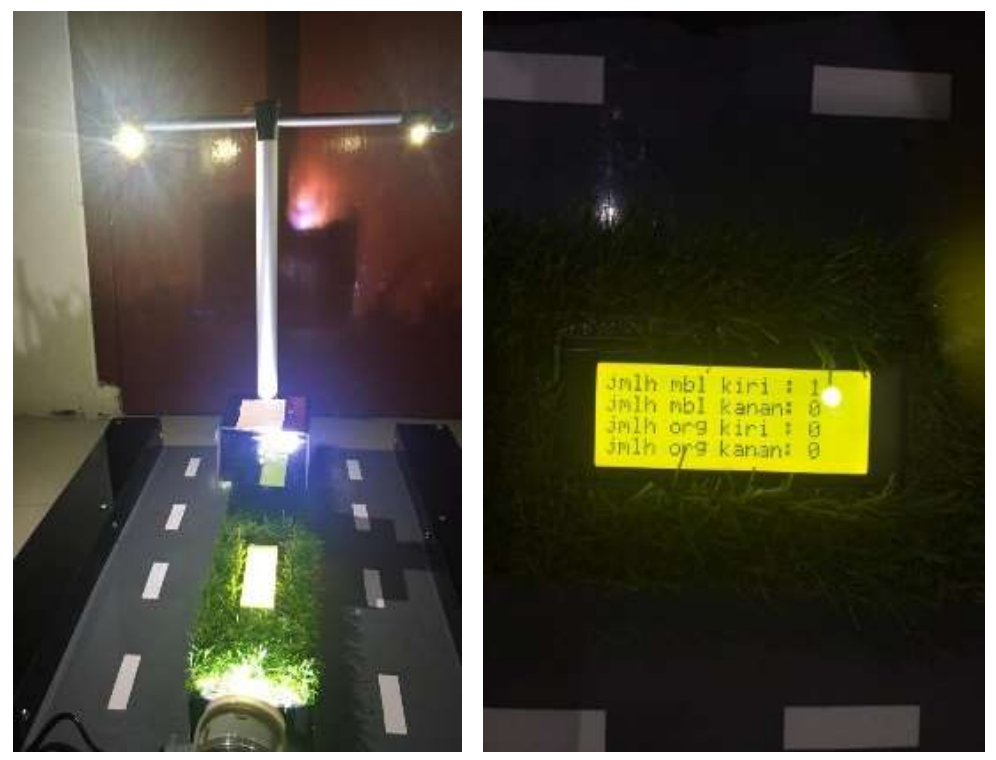

Gambar 16. Sensor LDR Kiri Mendeteksi

\section{Sensor PIR Kanan}

Gambar 17 merupakan kondisi lampu jalan ketika sensor PIR kanan mendeteksi adanya energi atau gerakkan dari makhluk hidup yang melewati jalan. Sehingga lampu akan hidup terang. Sensor PIR ini memiliki waktu delay saat sensor PIR berlogika 1 setelah dipicu oleh gerakkan hingga berlogika 0 kembali barulah lampu yang tadinya terang menjadi redup kembali. Dan LCD akan menampilkan bahwa sensor berhasil mendeteksi adanya gerakkan.
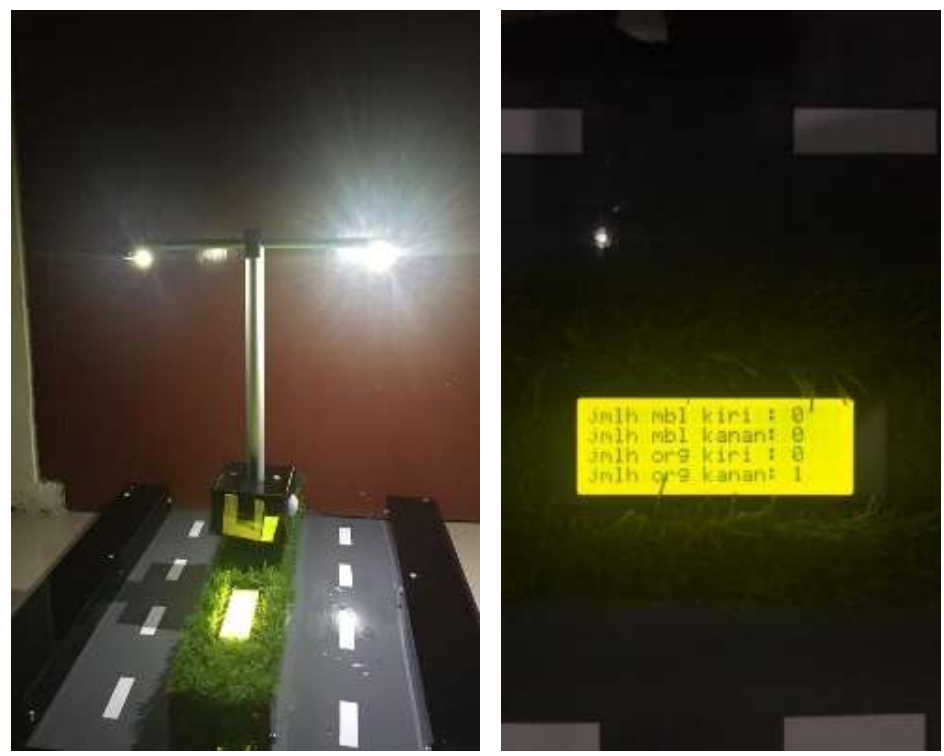

Gambar 17. Sensor PIR Kanan Mendeteksi 


\section{Sensor PIR Kiri}

Gambar 18 merupakan sensor PIR kiri mendeteksi adanya energi atau gerakkan dari makhluk hidup yang melewati jalan. Sehingga lampu kiri jalan menjadi lebih terang dibanding lampu kanan jalan. Dan LCD akan menampilkan data bahwa sensor PIR kiri berhasil mendeteksi adanya gerakkan yang melewati jalan.
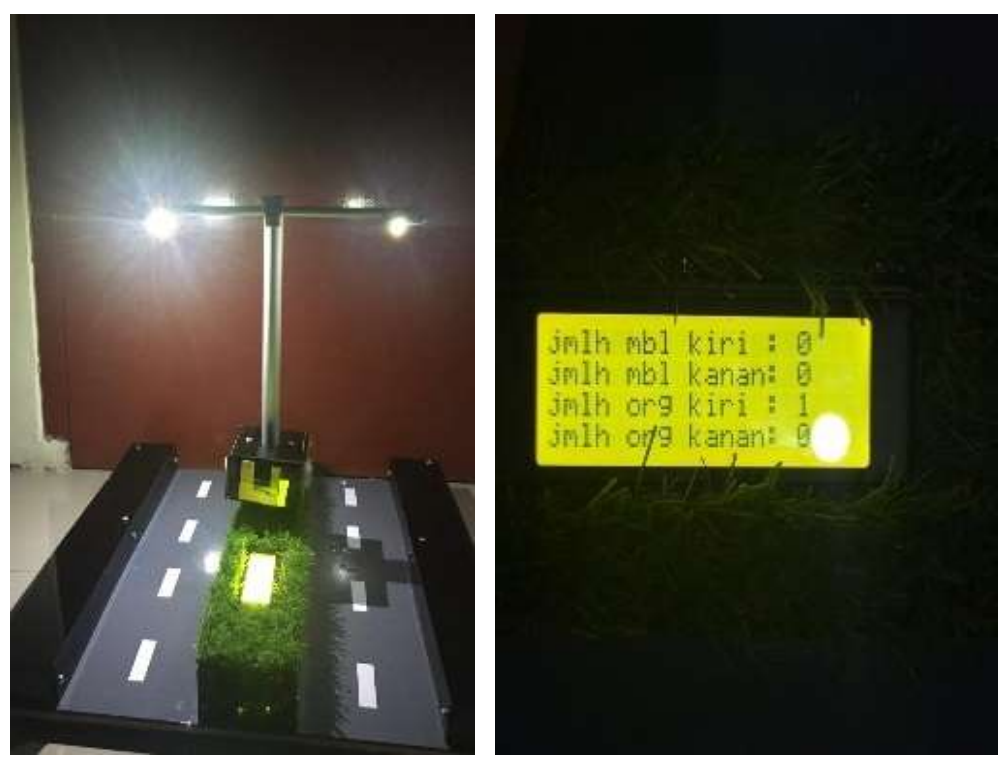

Gambar 18. Sensor PIR Kiri Mendeteksi

\section{SIMPULAN}

Berdasarkan hasil pengujian yang telah dikerjakan dapat ditarik kesimpulan bahwa sensor LDR pada alat ini berfungsi menangkap cahaya kendaraan yang melewati jalan raya sehingga lampu akan terang dan sensor PIR pada alat ini berfungsi mendeteksi gerakkan yang berasal dari makhluk hidup yang melewati jalan raya sehingga lampu juga akan terang. Sensor PIR ini memiliki waktu delay saat sensor PIR berlogika 1 setelah dipicu gerakkan sehingga berlogika 0 kembali maka lampu jalan akan kembali meredup

\section{REFERENSI}

[1] I. Hadie, "Sistem Pengendali Lampu Ruangan Menggunakan Sensor Motion Detection dan Sensor LDR Berbasis Mikroktroler AVR,” p. 24, 2018.

[2] U. S. Utara, U. S. Utara, and U. S. Utara, "Perancangan dan Pembuatan Smart Street Lamp Berbasis Mikrokontroller Atmega328p,” 2018.

[3] W. Purba, "Lampu Jalan Hemat Energi Otomatis Berbasis Mikrokontroler Arduino Uno," 2019.

[4] Mikrokontroller, "Sistem kendali," Jte, vol. 8, no. 2, pp. 25-34, 2004.

[5] "Rancang bangun sistem pengendali lampu pju berbasis mikrokontroller atmega328 menggunakan metode fuzzy mamdani." .

[6] S. SUPATMI, "Pengaruh Sensor Ldr Terhadap Pengontrolan Lampu," Maj. Ilm. UNIKOM, vol. 8, no. 2, pp. 175-180, 2010, [Online]. Available: http://jurnal.unikom.ac.id/_s/data/jurnal/v08-n02/volume-82-artikel-5.pdf/pdf/vol 
ume-82-artikel-5.pdf.

[7] J. Welman, "Prototype Penerangan Rumah Otomatis Berbasis Mikrokontroler ATMega8535," J. Sains, Teknol. dan Ind., no. 2, pp. 1-63, 2013.

[8] S. R. Hikmawan and E. A. Suprayitno, "Rancang Bangun Lampu Penerangan Jalan Umum (Pju) Menggunakan Solar Panel Berbasis Android (Aplikasi Di Jalan Parkiran Kampus 2 Umsida)," Elinvo (Electronics, Informatics, Vocat. Educ., vol. 3, no. 1, pp. 9-17, 2018, doi: 10.21831/elinvo.v3i1.15343.

[9] L. S. B. A. \& Wolfman, “済無No Title No Title,” J. Chem. Inf. Model., vol. 53, no. 9, pp. 1689-1699, 2013, doi: 10.1017/CBO9781107415324.004.

[10] B. A. B. Ii, "Pada Tabel 2.1 berikut menampilkan Senyawa Semikonduktor yang digunakan untuk menghasilkan variasi warna pada LED :," pp. 5-32. 